\title{
Article
}

\section{Evidence to Suggest that Women's Sexual Behavior is Influenced by Hip Width Rather than Waist-to-Hip Ratio}

Simpson, Victoria J., Brewer, Gayle and Hendrie, Colin A.

Available at http://clok.uclan.ac.uk/13569/

Simpson, Victoria J., Brewer, Gayle ORCID: 0000-0003-0690-4548 and Hendrie, Colin A. (2014) Evidence to Suggest that Women's Sexual Behavior is Influenced by Hip Width Rather than Waist-to-Hip Ratio. Archives of Sexual Behavior, 43 (7). pp. 1367-1371. ISSN 0004-0002

It is advisable to refer to the publisher's version if you intend to cite from the work. http://dx.doi.org/10.1007/s10508-014-0289-z

For more information about UCLan's research in this area go to http://www.uclan.ac.uk/researchgroups/ and search for <name of research Group>.

For information about Research generally at UCLan please go to http://www.uclan.ac.uk/research/

All outputs in CLoK are protected by Intellectual Property Rights law, including Copyright law. Copyright, IPR and Moral Rights for the works on this site are retained by the individual authors and/or other copyright owners. Terms and conditions for use of this material are defined in the policies page.

\section{CLoK}

Central Lancashire online Knowledge www.clok.uclan.ac.uk

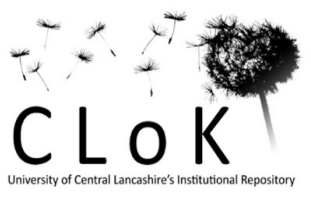




\title{
Evidence to Suggest That Women's Sexual Behavior Is Influenced by Hip Width Rather than Waist-to-Hip Ratio
}

\author{
Victoria J. Simpson, Gayle Brewer, and Colin A. Hendrie
}

Waist-to-hip ratio (WHR) is an important ornament display that signals women's health and fertility. Its significance derives from human development as a bipedal species. This required fundamental changes to hip morphology/musculature to accommodate the demands of both reproduction and locomotion. The result has been an obstetric dilemma whereby women's hips are only just wide enough to allow the passage of an infant. Childbirth therefore poses a significant hip width related threat to maternal mortality/risk of gynecological injury. It was predicted that this would have a significant influence on women's sexual behavior. To investigate this, hip width and WHR were measured in 148 women (M age $=20.93+.17$ years) and sexual histories were recorded via questionnaire. Data revealed that hip width per se was correlated with total number of sexual partners, total number of one night stands, percentage of sexual partners that were one night stands, number of sexual partners within the context of a relationship per year sexually active, and number of one night stands per year sexually active. By contrast, WHR was not correlated with any of these measures. Further analysis indicated that women who predominantly engaged in one night stand behavior had wider hips than those who did not. WHR was again without effect in this context. Women's hip morphology has a direct impact on their risk of potentially fatal childbirth related injury. It is concluded that when they have control over this, women's sexual behavior reflects this risk and is therefore at least in part influenced by hip width.

KEY WORDS: hip width; waist-to-hip ratio; obstetric dilemma; sexual behavior. 


\section{INTRODUCTION}

Previous research has shown that waist-to-hip ratio (WHR) is an important index of female attractiveness (Dixson, Grimshaw, Linklater, \& Dixson, 2011; Marlowe \& Wetsman, 2001; Singh, 1993) that signals both a woman's fertility (Zaadstra et al., 1993) and her general health (Czernichow et al., 2011). WHR also changes over women's lifetimes (Kirschner \& Samojlik, 1991) and so indicates residual reproductive value (Marlowe, 1998). It has therefore been proposed that WHR serves as an important ornament display (Perilloux, Webster, \& Gaulin, 2010; Singh, 1993) and much is now known about the effects of this (e.g., Dixson, Sagata, Linklater, \& Dixson, 2010; Karremans, Frakenhuis, \& Arons, 2010; Platek \& Singh, 2010; Singh, Dixson, Jessop, Morgan, \& Dixson, 2010; Swami, Jones, Einon, \& Furnham, 2009; Vaidya et al., 2012).

The significance of the female WHR derives from humans having developed as a bipedal species. The changes to hip morphology/musculature to accommodate this include the shortening and broadening of the ilia and the gluteus maximus becoming an extensor responsible for counteracting anterior flexion of the torso (Lieberman, Raichlen, Pontzer, Bramble, \& CutrightSmith, 2006). The gluteus medius and minimus are abductors in this context which contract to offset lateral flexing (Jannusson, 1991; Lovejoy, 1988). The efficiency of these abductors is to a large extent dependent on the width of the hips, as lateral flexing (and hence energy spent correcting this) is reduced when hips are relatively narrow (Lovejoy, 1988). Bipedal locomotion therefore exerts a pressure towards the narrowing of the hips.

The needs of childbirth, however, create demands in the opposite direction, i.e., for female pelves to be broad enough and structured in such a way to allow the passage of an infant. Adaptations to accommodate this include a transverse broadening of the pelvis and an increase in 
the anterior-posterior distance between the sacroiliac joint and the acetabula. There has also been a decrease in the protrusion of the sacrum anteriorly and an increase in the subpubic angle (Rosenberg, 1992; Wittman \& Wall, 2007). These birth-related pelvic modifications are relatively modest compared to those induced by the needs of bipedalism. Nonetheless, the conflicting demands of each have created an obstetric dilemma whereby childbirth is rendered difficult as women's hips are only just wide enough to allow an infant to be born (Rosenberg, 1992; Rosenberg \& Trevathan, 2002; Wittman \& Wall, 2007). Further complications are caused by neonate size remaining relatively constant regardless of variations in maternal size (Butte \& King, 2005; Mohanty et al., 2006), which places those with narrow pelvic outlets at greatest risk of Cephalopelvic Disproportion (CPD) (Stålberg, Bodestedt, Lyrenäs, \& Axelsson, 2006; Thurnau, Hales, \& Morgan, 1992).

In the developed world, where medical intervention is available, $22-28 \%$ of babies are now born by Caesarean delivery (Mayor, 2005; Walker, Hill, Burger, \& Hurtado, 2006). Where such assistance is not available (as would have been the case for most of human history), the lifetime risk of maternal mortality can reach as high as 1 in 7 , with a significant proportion of those women that survive childbirth suffering severe birth related gynecological injury (Arrowsmith, Hamlin, \& Wall, 1996; WHO, 2007). Birth trauma induced neonatal mortality rates are similarly affected (WHO, 2006). CPD is therefore extremely dangerous for both mothers and infants (Sheiner, Levy, Katz, \& Mazor, 2005) and women with the narrowest hips are at the greatest risk.

In this context, where opportunities for sexual encounters exist, it is women who decide, in all but the most extreme of circumstances, whether mating takes place or not (Clark \& Hatfield, 1989). Signals of fertility and attractiveness, such as WHR, serve to influence the 
number/quality of men available to them (e.g., Hendrie, Mannion, \& Godfrey, 2009). However, variations in hip width per se have a direct impact on women's risks of suffering serious birth related traumas and these have the potential to lead to permanent gynecological damage or even death. Therefore, it was predicted that there may be some relationship between women's hip width per se and their sexual behavior. The following studies were conducted in order to examine this hypothesis.

\section{METHOD}

\section{Participants}

A total of 148 female participants aged between 18 and 26 years $(M=20.93 \pm .17)$ were recruited by opportunity sampling from around the University of Leeds and its environs. No other recruitment measures were employed and no compensation was offered for taking part in the study.

\section{Procedure}

A number of physical measurements were recorded by a trained researcher who was blind to the hypothesis under investigation. Inter-observer reliability was established at $>99 \%$ on a number of volunteers who were also measured by a second researcher prior to the study beginning. Hip width was defined as the distance between the upper outer edges of the iliac crest bones of the pelvis. WHR was determined from measurements of hip circumference at the widest point and waist circumference at the narrowest point between the bottom of the rib cage and the top of the iliac crest. Participants also completed a questionnaire that asked them about their sexual histories, including age of virginity loss, number of sexual partners, and emotionally significant sexual relationships. Questions about sexual histories were phrased "How many sexual partners have you had in your lifetime? ", "How old were you when you 
lost your virginity?____ Years ___ Months” etc. Questions to do with relationships asked "Age at the start of the relationship?", "Relationship length?", Were you in love with this partner?" with details of each relationship being filled out on a new line. Data were also collected about participant's ages.

To control for participant's different ages at the time of taking part in the study and ages when they lost their virginities, data were also converted into sexual partners per year [sexually active] (sexual partners/(age - age at virginity loss)). Only women that had at least one sexual partner were included in the study. It should be noted that physical measurements including hip width and waist to hip ratio (WHR) were taken prior to the administration of questionnaires and results were not analyzed until data collection was complete. Studies were conducted in accordance with guidelines laid down by the British Psychological Society and approved by The University of Leeds Institute of Psychological Sciences ethics committee.

\section{RESULTS}

With regard to physical parameters of the study population, hip widths ranged from 28.0 to $46.0 \mathrm{~cm}(\mathrm{M}=34.64 \pm .28)$ and waist to hip ratios (WHR) from .65 to .94 . With respect to questions about sexual histories, age of virginity loss ranged from 13.9 to 23.7 years old $(\mathrm{M}=$ $16.96 \pm 0.14)$, total number of sexual partners ranged from 1 to $37(\mathrm{M}=5.94 \pm .53)$, and the subset of these that were one-night stands (hook-ups) from 0 to $36(\mathrm{M}=4.57 \pm .52)$.

Pearson's $r$ revealed that hip width per se was correlated with total number of sexual partners, total number of one night stands, percentage of sexual partners that were one night stands, number of sexual partners within the context of a relationship per year sexually active, and number of one night stands per year sexually active. By contrast, WHR was not correlated with any of these measures. See Table 1 for more details. 
The similarity of correlations with hip width and WHR were examined using Fisher's $r$ to $\mathrm{z}$ transformations. These revealed that only the correlations with number of sexual partners within the context of a relationship per year sexually active were significantly different, $\mathrm{Z}=$ $2.26, p<.05$.

Total number of sexual partners and total number of one night stands were correlated with much the same measures and so in the interests of brevity only the significant correlations relating to one night stands are presented. These were hip width, age at virginity loss, total number of sexual partners, number of sexual partners in the context of a relationship, one night stands expressed as a percentage of total sexual activity, one night stands per year sexually active, and number of years sexually active. Finally, number of one night stands per year sexually active was correlated with hip width, age at virginity loss, total number of sexual partners, total number of one night stands, number of one night stands expressed as a percentage of total sexual activity, and number of sexual partners per year sexually active. See Table 2 for further details.

For ease of presentation, data relating to one night stands were expressed as a percentage of total sexual activity and categorized according to women's hip widths (below 31, 31-32, 3334, 35-36, above $36 \mathrm{~cm}$ ). These data were analyzed by ANOVA and this showed a main effect of hip width category, $F(4,143)=3.51, p<.01$. Follow up tests (orthogonal contrasts) revealed this effect to be due to significant differences between women with hip widths greater than $36 \mathrm{~cm}$ and women with hip widths below $31 \mathrm{~cm}, F(1,143)=10.54, p<.01$, women with hip widths between 31-32 cm, $F(1,143)=5.06, p<.05,33-34 \mathrm{~cm}, F(1,143)=7.61, p<.01$, and $35-36 \mathrm{~cm}$, $F(1,143)=6.39, p<.05$. 
Further analysis was performed on data grouped according to one night stand behavior expressed as a percentage of total sexual activity: (1) those whose sexual activity comprised of less than $25 \%$ one night stands $(n=65, M=0.6 \% \pm .04)$; (2) those between 25 and $75 \%$ one night stands $(\mathrm{n}=55, \mathrm{M}=52.9 \% \pm 2.14)$, and those who had more than $75 \%$ one night stands $(\mathrm{n}$ $=28, \mathrm{M}=82.0 \% \pm 2.32$ ).

With respect to hip width, ANOVA showed there to be a significant main effect, $F(2$, $145)=3.90, p<.025$, which follow up tests (orthogonal contrasts) revealed to be due to those with $75 \%$ or more one night stands having significantly wider hips (in the order of $2 \mathrm{~cm}$ wider) than those with less than $25 \%, F(1,145)=6.44, p<.025$ and those between 25 and $74.9 \%$ one night stands, $F(1,145)=6.68, p<.01$.

No effects were seen with respect to WHR (main effect $F(2,145)<1$ ) and the difference between the WHR of those that engaged mainly in one night stand behavior (>75\%) and those that restricted their sexual activity to mainly within relationships $(<25 \%)$ was only $0.01(\mathrm{WHR}=$ $0.77 \pm .007$ vs $\mathrm{WHR}=0.78 \pm 0.01$ respectively $)$

These findings together indicate that numbers of sexual partners in this sample were largely driven by one night stand behavior and that this is correlated with hip width but not with WHR.

\section{DISCUSSION}

The current study was conducted in order to investigate the relative influence of hip width per se and WHR on self reports of women's sexual behavior. Data revealed that hip width per se was correlated with total number of sexual partners, total number of one night stands, percentage of sexual partners that were one night stands, number of sexual partners within the 
context of a relationship per year sexually active and number of one night stands per year sexually active. By contrast, WHR was not correlated with any of these measures.

Only one of the correlations with hip width was significantly different from the WHR results (number of sexual partners within the context of a relationship per year sexually active). Nonetheless more detailed analysis indicated that women who predominantly engaged in one night stand behavior had wider hips than those whose sexual activity was mainly within the context of a relationship. WHR was again without effect in this context. These data therefore indicate that hip width per se had a significant influence on women's sexual behavior while WHR had no measurable effects in this study.

Hip morphology is of significance for human sexual activity because of the obstetric dilemma that results from our species' bipedalism. This dilemma is produced by the competing demands of locomotion and childbirth. The former exerts a pressure towards the narrowing of hips while the latter exerts pressures in the opposite direction (Rosenberg \& Trevathan, 2002; Stewart, 1984; Wittman \& Wall, 2007). Female hips are in consequence only just wide enough to allow childbirth and human infants are born at a less developed stage than most other primates because of this restriction (DeSilva \& Lesnik, 2006; 2008). Birth is therefore followed by a long period of infant helplessness and vulnerability and this acts as a strong selection pressure towards the development of paternal investment. The outcomes for both mother and child are adversely affected if that investment is not made (Beise, 2005; Tymicki, 2006). This investment is more likely to be made if males are convinced that it is being directed at their own offspring and strong signals of future fidelity, such as those inferred from a male's knowledge of a female's sexual history (particularly those relating to one night stand behavior) are of importance in this respect (Thompson, 1983; Weiss \& Slosnerick, 1981). 
Thus while WHR may be of importance for influencing the number and quality of men available to women as potential sexual partners, hip width per se may be of relatively greater significance for her decision to engage in sex. Therefore, it is concluded that women's sexual behavior is influenced by their hip morphology rather than their WHR and this effect could be related to the variable risk of birth related traumas. Statements about causality cannot be made using the current data set and it remains to be seen if these conclusions can be generalized to other populations and cultures. 


\section{REFERENCES}

Arrowsmith, S., Hamlin, E. C., \& Wall, L. L. (1996). Obstructed labor injury complex: Obstetric fistula formation and the multifaceted morbidity of maternal birth trauma in the developing world. Obstetrical \& Gynecological Survey, 51, 568-574.

Beise, J. (2005). The helping grandmother and the helpful grandmother: The role of maternal and paternal grandmothers in child mortality in the $17^{\text {th }}$ and $18^{\text {th }}$ century population of French settlers in Quebec, Canada. In E. Voland, A. Chasiotis, \& W. Schiefenhoevel (Eds.), Grandmotherhood: The evolutionary significance of the second half of the female life (pp. 215-238). New Brunswick, NJ: Rutgers University Press.

Butte, N. F., \& King, J. C. (2005). Energy requirements during pregnancy and lactation. Public Health Nutrition, 8, 1010-1027.

Clark, R. D., \& Hatfield, E. (1989). Gender differences in receptivity to sexual offers. Journal of Psychology and Human Sexuality, 2, 39-55.

Czernichow, S., Kengne, A. P., Huxley, R. R., Batty, G. D., de Galan, B., Grobbee, D., ... ADVANCE Collaborative Group. (2011). Comparison of waist-to-hip ratio and other obesity indices as predictors of cardiovascular disease risk in people with type-2 diabetes: A prospective cohort study from ADVANCE. European Journal of Cardiovascular Prevention \& Rehabilitation, 18, 312-319.

DeSilva, J., \& Lesnik, J. (2006). Chimpanzee neonatal brain size: Implications for brain growth in Homo erectus. Journal of Human Evolution, 51, 207-212.

DeSilva, J. M., \& Lesnik, J. J. (2008). Brain size at birth throughout human evolution: A new method for estimating neonatal brain size in hominins. Journal of Human Evolution, 55, 1064-1074. 
Dixson, B. J., Grimshaw, G. M., Linklater, W. L., \& Dixson, A. F. (2011). Eye-tracking of men's preferences for waist-to-hip ratio and breast size of women. Archives of Sexual Behavior, 40, 43-50.

Dixson, B. J., Sagata, K., Linklater, W. L., \& Dixson, A. F. (2010). Male preferences for female waist-to-hip ratio and body mass index in the highlands of Papua New Guinea. American Journal of Physical Anthropology, 141, 620-625.

Hendrie, C. A., Mannion, H. D., \& Godfrey, G. K. (2009). Evidence to suggest that nightclubs function as human sexual display grounds. Behaviour, 146, 1331-1348.

Jaanusson, V. (1991). Morphological changes leading to hominid bipedalism. Lethaia, 24, 443457.

Karremans, J. C., Frankenhuis, W. E., \& Arons, S. (2010). Blind men prefer a low waist-to-hip ratio. Evolution and Human Behavior, 31, 182-186.

Kirschner, M. A., \& Samojlik, E. (1991). Sex hormone metabolism in upper and lower body obesity. International Journal of Obesity, 15, 101-108.

Lieberman, D. E., Raichlen, D. A., Pontzer, H., Bramble, D. M., \& Cutright-Smith, E. (2006). The human gluteus maximus and its role in running. Journal of Experimental Biology, $209,2143-2155$.

Lovejoy, C. O. (1988). Evolution of human walking. Scientific American, 259, 118-125.

Marlowe, F. (1998). The nubility hypothesis: The human breast as an honest signal of residual reproductive value. Human Nature, 9, 263-271.

Marlowe, F., \& Wetsman, A. (2001). Preferred waist-to-hip ratio and ecology. Personality and Individual Differences, 30, 481-489 
Mayor, S. (2005). 23\% of babies in England are delivered by caesarean section. British Medical Journal, 330, 806.

Mohanty, C., Prasad, R., Reddy, A. S., Ghosh, J. K., Singh, T. B., \& Das, B. K. (2006). Maternal anthropometry as predictors of low birth weight. Journal of Tropical Pediatrics, 52, 2429.

Perilloux, H. K., Webster, G. D., \& Gaulin, S. J. C. (2010).Signals of genetic quality and maternal investment capacity: The dynamic effects of fluctuating asymmetry and waistto-hip ratio on men's ratings of women's attractiveness. Social Psychological and Personality Science, 1, 34-42.

Platek, S. M., \& Singh, D. (2010). Optimal waist-to-hip ratios in women activate neural reward centers in men. PloS One, 5, e9042.

Rosenberg, K. R. (1992). The evolution of modern human childbirth. American Journal of Physical Anthropology, 35, 89-124.

Rosenberg, K., \& Trevathan, W. (2002). Birth, obstetrics and human evolution. British Journal of Obstetrics \& Gynecology, 109, 1199-1206.

Sheiner, E., Levy, A., Katz, M., \& Mazor, M. (2005). Short stature-an independent risk factor for Cesarean delivery. European Journal of Obstetrics \& Gynecology and Reproductive Biology, 120, 175-178.

Singh, D. (1993). Adaptive significance of female physical attractiveness: Role of waist-to-hip ratio. Journal of Personality and Social Psychology, 65, 293-307.

Singh, D., Dixson, B. J., Jessop, T. S., Morgan, B., \& Dixon, A. F. (2010). Cross-cultural consensus for waist-to-hip ratio and women's attractiveness. Evolution and Human Behavior, 31, 176-181. 
Stålberg, K., Bodestedt, Å., Lyrenäs, S., \& Axelsson, O. (2006). A narrow pelvic outlet increases the risk for emergency cesarean section. Acta Obstetricia et Gynecologica Scandinavica, 85, 821-824.

Stewart, D. B. (1984). The pelvis as passageway II. The modern human pelvis. British Journal of Obstetrics \& Gynecology, 91, 618-623.

Swami, V., Jones, J., Einon, D., \& Furnham, A. (2009). Men's preferences for women's profile waist-to-hip ratio, breast size, and ethnic group in Britain and South Africa. British Journal of Psychology, 100, 313-325.

Thompson, A. (1983). Extramarital sex: A review of the research literature. Journal of Sex Research, 19, 1-22.

Thurnau, G. R., Hales, K. A., \& Morgan, M. A. (1992). Evaluation of the fetal-pelvic relationship. Clinical Obstetrics \& Gynecology, 35, 570-581.

Tymicki, K. (2006). The correlates of infant and childhood mortality: A theoretical overview and new evidence from the analysis of longitudinal data from Bejsce parish register reconstitution study $18^{\text {th }}-20^{\text {th }}$ centuries, Poland. Paper presented at the Population Association of America Annual Conference, Los Angeles.

Vaidya, D., Dobs, A., Gapstur, S. M., Golden, S. H., Cushman, M., Liu, K., \& Ouyang, P. (2012). Association of baseline sex hormone levels with baseline and longitudinal changes in waist-to-hip ratio: Multi-ethnic study of atherosclerosis. International Journal of Obesity, 36, 1578-1584.

Walker, R., Hill, K., Burger, O., \& Hurtado, A. M. (2006). Life in the slow lane revisited: Ontogenetic separation between chimpanzees and humans. American Journal of Physical Anthropology, 129, 577-583. 
Weiss, D. L., \& Slosnerick, M. (1981). Attitudes toward sexual and non-sexual extramarital involvements among a sample of college students. Journal of Marriage and Family, 43, $349-358$.

WHO. (2006). Neonatal and perinatal mortality: Country, regional and global estimates, 2006. Geneva.

WHO. (2007). Maternal mortality in 2005: Estimates developed by WHO, UNICEF, UNFPA, and the World Bank, Geneva.

Wittman, A. B., \& Wall, L. (2007). The evolutionary origins of obstructed labor: Bipedalism, encephalization, and the human obstetric dilemma. Obstetric \& Gynecological Survey, $62,739-748$.

Zaadstra B. M., Seidell, J. C., Van Noord, P. A., te Velde, E. R., Habbema, J. D., Vrieswijk, B., \& Karbaat, J. (1993). Fat and female fecundity: Prospective study of effect of body fat distribution and conception rates. British Medical Journal, 306, 484-487. 
Table 1. Hip width and waist to hip ratio (WHR) correlations with various measures of women's sexual activity.

\begin{tabular}{|c|c|c|c|c|}
\hline \multirow[t]{2}{*}{ Measure of Sexual Activity } & \multicolumn{2}{|c|}{ Hip Width } & \multicolumn{2}{|c|}{ WHR } \\
\hline & Pearson's $r$ & $p$ & Pearson's $r$ & $p$ \\
\hline $\begin{array}{c}\text { Total number of sexual } \\
\text { partners }\end{array}$ & .19 & .017 & .072 & ns \\
\hline $\begin{array}{l}\text { Total number of one night } \\
\text { stands }\end{array}$ & .20 & .011 & .084 & ns \\
\hline $\begin{array}{l}\text { One night stands as percent of } \\
\text { total sexual activity }\end{array}$ & .19 & .017 & .055 & ns \\
\hline $\begin{array}{c}\text { Number of sexual partners } \\
\text { within the context of a } \\
\text { relationship per year sexually } \\
\text { active }\end{array}$ & -.22 & .007 & .054 & ns \\
\hline $\begin{array}{l}\text { Number of one night stands } \\
\text { per year sexually active }\end{array}$ & .23 & .004 & .087 & ns \\
\hline
\end{tabular}


Table 2. Correlations with one night stands (hook-ups)/one night stands per year sexually active.

\begin{tabular}{|c|c|c|c|c|}
\hline \multirow[t]{2}{*}{ Measure } & \multicolumn{2}{|c|}{$\begin{array}{l}\text { Total Number of One } \\
\text { Night Stands }\end{array}$} & \multicolumn{2}{|c|}{$\begin{array}{c}\text { Number of One Night } \\
\text { Stands Per Year Sexually } \\
\text { Active }\end{array}$} \\
\hline & Pearson's $r$ & $p$ & Pearson's $r$ & $p$ \\
\hline Hip width & .20 & .011 & .23 & .004 \\
\hline Age at virginity loss & -.36 & .000 & -.01 & ns \\
\hline $\begin{array}{c}\text { Total number of sexual } \\
\text { partners }\end{array}$ & .99 & .000 & .71 & .000 \\
\hline $\begin{array}{l}\text { Sexual partners in context of } \\
\text { relationship }\end{array}$ & -.24 & .003 & -.12 & ns \\
\hline $\begin{array}{l}\text { Total number of one night } \\
\text { stands }\end{array}$ & & & .73 & .000 \\
\hline $\begin{array}{l}\text { One night stands as percent of } \\
\text { total sexual activity }\end{array}$ & .60 & .000 & .59 & .000 \\
\hline $\begin{array}{c}\text { Number of sexual partners per } \\
\text { year sexually active }\end{array}$ & .64 & .000 & .95 & .000 \\
\hline $\begin{array}{l}\text { Number of one night stands } \\
\text { per year sexually active }\end{array}$ & .73 & .000 & & \\
\hline $\begin{array}{c}\text { Number of years sexually } \\
\text { active }\end{array}$ & .37 & .000 & -.02 & ns \\
\hline
\end{tabular}

